\title{
EDUKASI GERAKAN HIDUP SEHAT DENGAN AKTIVITAS FISIK PADA WALI MURD PAUD GEMILANG, KELURAHAN BENDA BARU
}

\author{
${ }^{1)}$Ernyasih $^{*}{ }^{2)}$ Elsa Sylvania Sari, ${ }^{3)}$ Najwa Khairina, ${ }^{4)}$ Munaya Fauziah, ${ }^{5)}$ Andriyani, \\ ${ }^{6)}$ Triana Srisantyorin, ${ }^{7)}$ Aragar Putri \\ ${ }^{1,2,4,5,6,7)}$ Program Studi Kesehatan Masyarakat, Universitas Muhammadiyah Jakarta \\ ${ }^{3)}$ Jurusan Ekonomi dan Studi Pembangunan, UIN Syarif Hidayatullah \\ *alamat: Jl. K. H Ahmad Dahlan, Cirendeu, Ciputat \\ *Email: ummi.rifali@gmail.com
}

\begin{abstract}
ABSTRAK
Perilaku Hidup Bersih dan Sehat merupakan suatu bentuk perilaku keseharian yang sangat penting untuk dilakukan karena mendukung terciptanya kualitas hidup yang lebih baik. Gaya hidup masyarakat sekarang lebih menyukai makanan siap saji, dimana makanan tersebut banyak mengandung lemak, protein, tinggi garam dan rendah serat. Gaya hidup seperti ini dapat menyebabkan berbagai masalah kesehatan antara lain hipertensi, gagal jantung, diabetes mellitus, stroke dan penyakit ginjal. Dari hasil Musyawarah Masyarakat Desa maka didapatkan satu permasalahan kesehatan di wilayah kerja UPT Puskesmas Benda Baru khususnya di RW 003 yaitu kurangnya aktivitas Fisik, kurangnya konsumsi buah dan sayur dan merokok. Metode yang digunakan adalah pre dan post test serta edukasi gerakan sehat dengan aktivitas fisik. Kegiatan penyuluhan ini meningkatkan pengetahuan dan kesadaran masyarakat mengenai pentingnya melakukan aktivitas fisik untuk menurunkan faktor risiko terjadinya Penyakit tidak menular khususnya penyakit Hipertensi wali murid PAUD Gemilang.
\end{abstract}

Kata Kunci: Edukasi, Hidup sehat, aktivitas fisik

\section{ABSTRACT}

Clean and Healthy Living Behavior is a form of daily behavior that is very important to do because it supports the creation of a better quality of life. The lifestyle of people now prefers ready-to-eat food, where these foods contain lots of fat, protein, high salt and low fiber. This lifestyle can cause various health problems including hypertension, heart failure, diabetes mellitus, stroke, and kidney disease. From the results of the Village Community Meeting, one health problem was found in the work area of the Benda Baru Health Center, especially in RW 003, namely lack of physical activity, lack of consumption of fruits and vegetables and smoking. The method used was pre and post-test and healthy movement education with physical activity. This counseling activity increases public knowledge and awareness about the importance of doing physical activity to reduce risk factors for non-communicable diseases, especially hypertension, guardians of PAUD Gemilang students.

Keyword : Education, Healthy life, physical activity 


\section{PENDAHULUAN}

Gaya hidup masyarakat sekarang lebih menyukai makanan siap saji, dimana makanan tersebut banyak mengandung lemak, protein, tinggi garam dan rendah serat (Astuti, 2017). Hal tersebut menyebabkan berbagai masalah kesehatan antara lain hipertensi, gagal jantung, diabetes mellitus, stroke dan penyakit ginjal. Hipertensi esensial (primer) merupakan penyakit urutan kedua setelah infeksi saluran nafas bagian atas akut dari sepuluh besar penyakit rawat jalan di Rumah Sakit tahun 2010 (Kemenkes RI, 2012).

Hidup sehat merupakan suatu hal yang seharusnya memang diterapkan oleh setiap orang, mengingat manfaat kesehatan yang sangat penting bagi setiap manusia agar terhindar dari berbagai peyakit (Putri, 2019). Perilaku Hidup Bersih dan Sehat (PHBS) merupakan suatu bentuk perilaku keseharian yang sangat penting untuk dilakukan karena mendukung terciptanya kualitas hidup yang lebih baik (Rahmawati, 2019). Perilaku Hidup Bersih dan Sehat (PHBS) adalah semua perilaku kesehatan yang dilakukan atas kesadaran sehingga anggota keluarga atau keluarga dapat menolong dirinya sendiri di bidang kesehatan dan dapat berperan aktif dalam kegiatan - kegiatan kesehatan dan berperan aktif dalam kegiatan-kegiatan kesehatan di masyarakat(Musdalifah, Daud and Pagarra, 2016).

Menteri Kesehatan Republik Indonesia telah membuat Pedoman Pembinaan Perilaku Hidup Bersih dan Sehat yang tertuang dalam Peraturan Menteri Kesehatan Republik Indonesia Nomor: 2269/MENKES/PER/XI/2011 yang mengatur upaya peningkatan perilaku hidup bersih dan sehat atau disingkat PHBS di seluruh Indonesia dimana terdapat sepuluh indikator, yaitu persalinan, ASI ekslusif, timbang balita, ketersediaan air bersih, cuci tangan dengan air bersih dan menggunakan sabun, jamban sehat, berantas jentik, makan sayur dan buah, aktivitas fisik dan tidak merokok.

Menurut hasil Riskesdas (2018) prevalensi hipertensi di Banten sebesar 8.61\% sedangkan di Indonesia sebesar $8.36 \%$. Dan menurut hasil pengembangan PIS-PK di wilayah RW 003 kelurahan benda baru bahwa cakupan aktivitas fisik dan hipertensi memiliki cakupan yang rendah yaitu $37 \%$ untuk aktivitas fisik dan 23,35\% untuk hipertensi. Maka dari itu penulis bertujuan untuk melakukan intervensi agar masyarakat bisa paham mengenai pentingnya Aktivitas fisik untuk menghindari penyakit tidak menular seperti Hipertensi.

Berdasarkan hasil dari pengambilan data mengenai PIS-PK (Program Indonesia Sehat dengan Pendekatan Keluarga) dan penilaian terhadap indikator pengembangan PHBS (Perilaku Hidup Bersih dan Sehat) juga faktor risiko penyakit dan dari hasil Musyawarah Masyarakat Desa maka didapatkan satu permasalahan kesehatan di wilayah kerja UPT Puskesmas Benda Baru khususnya di RW 003 yaitu kurangnya aktivitas Fisik, kurangnya konsumsi buah dan sayur dan merokok.

Kegiatan ini bertujuan untuk meningkatkan pengetahuan dan kesadaran masyarakat mengenai pentingnya melakukan aktivitas fisik untuk menurunkan factor risiko terjadinya Penyakit tidak menular (PTM) khususnya penyakit Hipertensi.

\section{METODE}

Kegiatan pengabdian masyarakat dilaksanakan pada tanggal 13 Februari 2020 pada wali murid di PAUD Gemilang RW 003 Kelurahan Benda Baru, Kecamatan Pamulang, Kota Tangerang Selatan, Banten. Metode yang digunakan dalam kegiatan ini dibagi menjadi tiga tahap. Tahap pertama yaitu tim pengabdian melakukan pre-test terhadap peserta. Tahap kedua yaitu edukasi gerakan sehat dengan aktivitas fisik. Kemudian tahap ketiga yaitu posttest pada peserta. Bahan yang disiapkan adalah lembar kuesioner dan materi mengenai edukasi gerakan sehat dengan aktivitas fisik 
AS-SYIFA: Jurnal Pengabdian dan Pemberdayaan Kesehatan Masyarakat

\section{HASIL DAN PEMBAHASAN}

Kegiatan pengabdian masyarakat dibagi menjadi tiga tahap, antara lain :

1. Tahap Pertama : Pre-test terhadap peserta

Kegiatan Pre test bertujuan untuk mengukur tingkat pengetahuan masyarakat mengenai pentingnya aktivitas fisik untuk mencegah Penyakit Tidak menular khususnya Hipertensi yang dilakukan. Kegiatan pre test ini dilaksanakan sebelum kegiatan penyuluhan guna mengetahui sejauh mana pengetahuan masyarakat sebelum dilakukan penyuluhaan. Media yang digunakan dalam pre test adalah kertas berisi beberapa pertanyaan mengenai aktifitas fisik dan nantinya akan dinilai.

Menurut Purwanto (2012), pretest adalah tes yang diberikan sebelum penyuluhan dimulai, dan bertujuan untuk mengetahui sampai dimana penguasaan siswa terhadap bahan pengajaran (pengetahuan dan ketrampilan) yang akan diajarkan. Dalam hal ini pretest adalah melihat sampai dimana keefektifan pengajaran, setelah hasil pretesttersebut nantinya dibandingkan dengan hasil posttest.

Tes awal mempunyai fungsi, antara lain dapat menunjukkan kepada guru tujuan mana yang sudah dicapai. Dengan demikian guru dapat menentukan dimana ia harus memulai bahan pelajaran itu. Isi atau materi tes awal pada umunya ditekankan pada bahanbahan penting yang seharusnya sudah diketahui atau dikuasai oleh peserta didik sebelum pelajaran diberikan kepada mereka. Hasil pre test yang dilakukan pada peserta wali murid PAUD Gemilang didapatkan rata-rata skornya 45,33.

\section{Tahap Kedua : Edukasi gerakan sehat dengan aktivitas fisik}

Edukasi diberikan melalui penyuluhan dan diputarkan video mengenai aktivitas fisik berupa olah raga. Penyuluhan ini mendapat respon yang positif bagi wali murid PAUD Gemilang, hal ini terlihat dari banyaknya peserta yang bertanya.

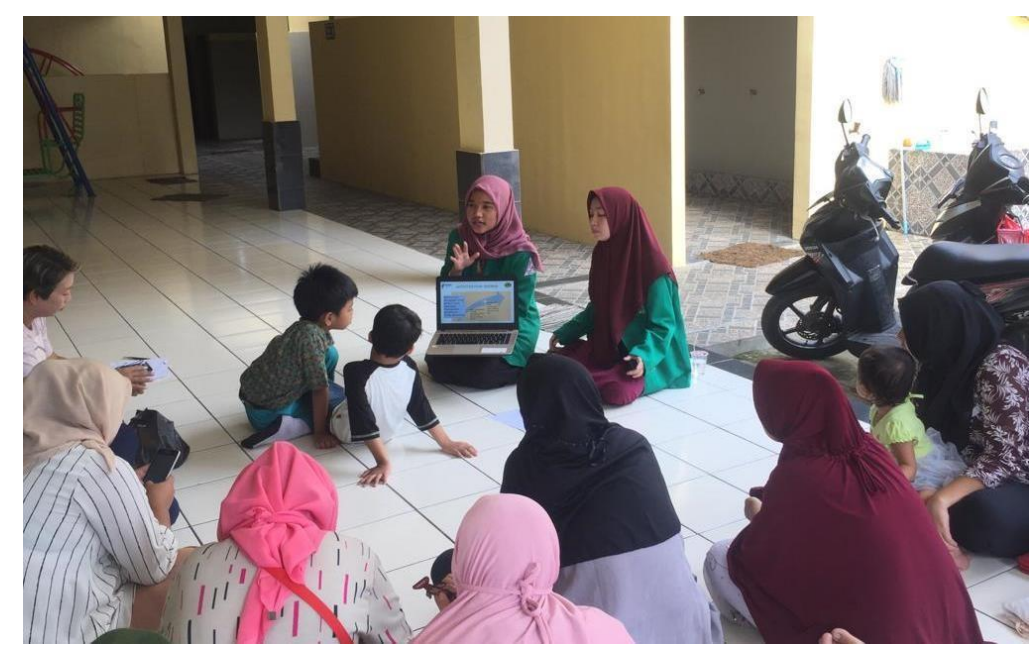

Sumber : Dokumentasi primer, 2020

Gambar 1. Penyuluhan terhadap wali murid PAUD Gemilang

3. Tahap Ketiga : post test pada peserta

Kegiatan post test dilakukan setelah penyuluhan dilakukan agar dilihat adakan perubahan pengetahuan dari peserta. Hasil post test yang dilakukan rata-rata skornya 82,67. 
AS-SYIFA: Jurnal Pengabdian dan

Pemberdayaan Kesehatan Masyarakat

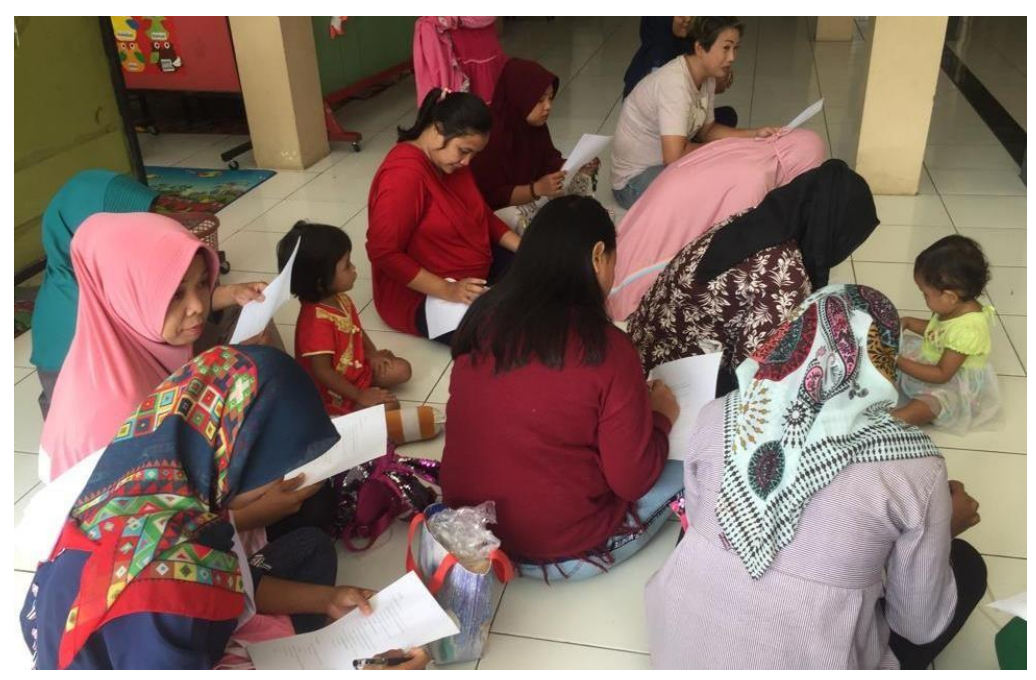

Sumber : Dokumentasi primer, 2020

Gambar 2. pre dan post-test pada wali murid PAUD Gemilang

Analisis data dilakukan terhadap wali murid PAUD Gemilang yang telah mengisi kuesioner pre dan post-test secara lengkap.

\section{Grafik 1. Distribusi Tingkat Pengetahuan Responden Sebelum dan sesudah penyuluhan}

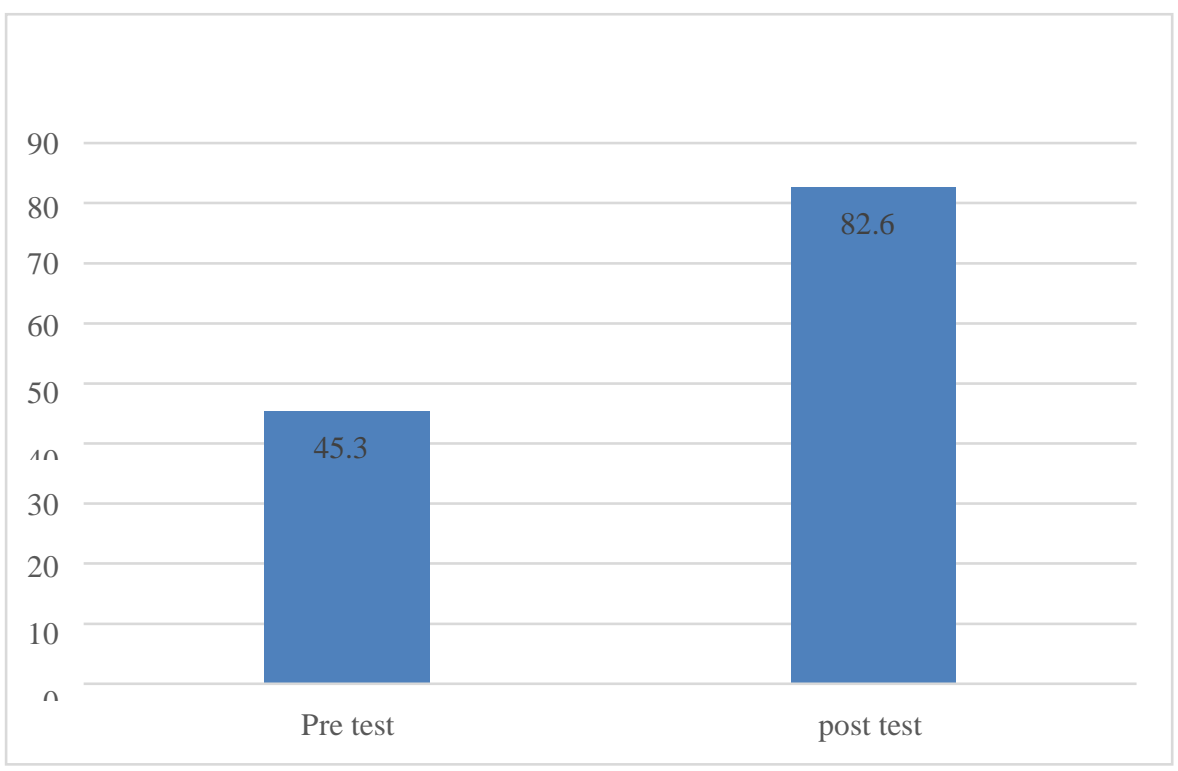

Berdasarkan grafik diatas dapat dilihat bahwa terdapat peningkatan rata-rata skor pengetahuan secara umum sebelum dan setelah pemberian penyuluhan. Rata-rata skor awal sebelum pemberian penyuluhan adalah 45,33 sedangkan setelah diberikan penyuluhan, ratarata skor pengetahuan meningkat menjadi 82,67. 
AS-SYIFA: Jurnal Pengabdian dan

Pemberdayaan Kesehatan Masyarakat

\section{KESIMPULAN DAN SARAN}

Kegiatan yang dilakukan oleh mahasiswa dan dosen sebagai tim pengabdian masyarakat Fakultas Kesehatan Masyarakat Universitas Muhammadiyah Jakarta mendapatkan respon yang positif dari wali murid PAUD Gemilang RW 003 Kelurahan Benda Baru, Kecamatan Pamulang, Kota Tangerang Selatan. Kegiatan penyuluhan ini meningkatkan pengetahuan wali murid PAUD Gemilang.

\section{UCAPAN TERIMA KASIH}

Ucapan terima kasih kepada UPT penelitian dan pengabdian masyarakat Fakultas Kesehatan Masyarakat dan Pengurus PAUD Gemilang.

\section{DAFTAR PUSTAKA}

Astuti, H. P. 2017. Pengaruh Senam Hipertensi Terhadap Penurunan Tekanan Darah Di Desa Blembem Wilayah Kerja Puskesmas Gondangrejo. Jurnal Kesehatan Kusuma Husada.

Kementerian Kesehatan Republik Indonesia. RISKESDAS 2018.

Musdalifah, M., Daud, F. And Pagarra, H. 2016. Analisis Perilaku Hidup Bersih Dan Sehat (PHBS) Masyarakat Desa Nelayan Di Kabupaten Takalar. Prosiding Seminar Nasional Biologi Vi.

Ngalim Purwanto, Prinsip-prinsip dan Teknik Evaluasi Pengajaran (Bandung : Remaja Rosdakarya, 2012

Putri, R. M. 2019. Gambaran Penerapan Perilaku Hidup Bersih Dan Sehat (PHBS) Lansia Pada Tatanan Rumah Tangga. Visikes : Jurnal Kesehatan Masyarakat Universitas Dian Nusawantoro Semarang.

Peraturan Menteri Kesehatan Republik Indonesia Nomor 2269/MENKES/PER/XI/2011 tentang Pedoman Pembinaan Perilaku Hidup Bersih dan Sehat.

Rahmawati, E. dkk. 2019. Sosialisasi Dan Harmonisasi Gerakan Masyarakat Hidup Sehat ( Germas ) Dan Program Indonesia Sehat Dengan Pendekatan Keluarga (PIS-PK) Di Kota Sukabumi. Link Poltekkes Semarang. Doi: 10.31983/Link.V15i1.4385. 
